Journal of Chromatography, 496 (1989) 335-344

Biomedical Applications

Elsevier Science Publıshers B V, Amsterdam - Printed in The Netherlands

CHROMBIO 4953

\title{
SENSITIVE HIGH-PERFORMANCE LIQUID CHROMATOGRAPHIC ASSAY USING 9-FLUORENYLMETHYLCHLOROFORMATE FOR MONITORING CONTROLLED-RELEASE LIDOCAINE IN PLASMA
}

\section{AMNON SINTOV}

Department of Pediatrics, CS Mott Children's Hosputal, and Department of Pharmaceutics, College of Pharmacy, University of Michigan, Ann Arbor, MI 48109 (US A)

\section{RIVKA SIDEN}

Department of Pediatrics, CS Mott Chuldren's Hospital, University of Michigan Medical School, Ann Arbor, MI 48109 (U S A)

and

\section{ROBERT J LEVY*}

Division of Pediatric Cardiology, CS Mott Children's Hospital, and Department of Phormaceutıcs, College of Pharmacy, University of Michigan, Ann Arbor, MI 48109 (US A)

(First received September 15th, 1988, revised manuscript recelved July 14th, 1989)

\section{SUMMARY}

A sensitive high-performance hquid chromatographic (HPLC) assay using fluorescence detection for quantıfying lidocaine levels in plasma ( $\mathrm{m}$ the $\mathrm{ng} / \mathrm{ml}$ range) was developed This novel HPLC assay has made possible the simultaneous monitoring of lidocaine levels in coronary and peripheral plasma obtained after myocardial controlled-release matrix administration (092 $\mathrm{mg} / \mathrm{kg}$ during $4 \mathrm{~h}$ ) in the arrhythmic dog The method employed extracts the drug from plasma using 1-chlorobutane and a subsequent derivatization with 9-fluorenylmethylchloroformate in acetonitrile at $110^{\circ} \mathrm{C}$ The derivative was chromatographed on a $\mathrm{C}_{18}$ reversed-phase column and measured with fluorescence detection (excitation $254 \mathrm{~nm}$, emission $313 \mathrm{~nm}$ ) N-Methylephedrine was found to be suitable as an internal standard, post-derivatization The derivatization product of lidocame was identıfied and characterized by mass spectral analysis It was found to have a unique and reproducible dicarbamate structure, which was stable for at least three days at room temperature The method was tested with human plasma as well as on dog plasma Analytical recoveries were $886 \pm 36$ and $774 \pm 30 \%$ (mean $\pm \mathrm{SE}$ ), respectively, at levels ranging from 25 to $200 \mathrm{ng} / \mathrm{ml}$ The lower detection limit was $1 \mathrm{ng} / \mathrm{ml}$ lıdocaine In conclusion, this rapid and 
convenient analysis was found to be suitable for the bioavallability pharmacokinetic assessment of hdocane following low-dose regional drug administration

\section{INTRODUCTION}

Lidocaine (2-diethylamıno-2' ${ }^{\prime} 6^{\prime}$-acetoxylıdıde) has been widely employed intravenously in the treatment of ventricular arrhythmias [1,2] High-performance liquid chromatographic (HPLC) analysis offers a convenient and routıne methodology for lidocaine monitoring (see, e.g., refs. 3-8). Thus far, there has not been any need for a particularly sensitive method to monitor plasma lidocaine levels during therapy. The reason for this has been the high therapeutıc range of lidocaine levels in plasma $(1.5-6 \mathrm{mg} / \mathrm{l})$ following intravenous administration $[9,10]$, which is easily quantitated using UV detection.

During our investigations of the site-specific treatment of experimental ventricular tachycardia (VT) in dogs by using epicardial controlled-release lidocaine, exceedingly low doses of drug were effectıve (300-400 $\mu \mathrm{g} / \mathrm{kg}$ during $4 \mathrm{~h}$ of administration) to convert VT to sinus rhythm [11,12] In these studies the systemic plasma lidocaine levels were undetectable with HPLC and UV detection methodology [12].

In order to conduct pharmacokınetıc studıes usıng epıcardıal administration, a more sensitive method for monitoring lidocaune in plasma needed to be developed. In addition, our particular experimental application required analysis on relatively small volumes of blood samples $(03-0.5 \mathrm{ml})$, mainly because of the limited amount of blood that can rapidly be obtained from the coronary blood vessels

In this paper we describe a new sensitive fluorescence HPLC assay for the routıne quantitatıve determination of lidocaine in plasma. We have used a new chloroformate reagent (9-fluorenylmethylchloroformate, 9-FMClF), which has recently been used as an amino-protectıve group in peptide synthesis $[13,14]$ and as a derivatizing agent reactıng with the piperıdıne moiety of pirlimycin [15]. The objectıves of this paper were (a) to develop a more sensitive assay for monitoring coronary plasma levels of lidocaine, (b) to examıne the in vivo applicability of this assay in pharmacokınetic studies in dogs treated with cardiac controlled-release lidocaine, and (c) to determine if this methodology could be applicable to human plasma samples.

\section{EXPERIMENT $\Lambda$ L}

\section{Chemicals}

Lidocaine hydrochloride was provided by Abbott Labs. (Chicago, IL, U S A.) Lidocaine free base was obtained from Sigma (St. Louıs, MO, U S A ) Ethylmethylglycylxylıdıde (EMGX) was obtained from Astra (Worcester, MA, 
U S.A.). $1 R, 2 R-(\Psi)$-N-Methyl-4-ephedrine (NME) was obtained from Sigma. Stock solutions of lidocaine hydrochloride and NME in water were prepared at concentrations of 1 and $10 \mu \mathrm{g} / \mathrm{ml}$, respectively. Stock solutions of lidocaine free base and NME in anhydrous acetonitrile were also prepared. 9-FMClF was obtained from Aldrich (Milwaukee, WI, U.S.A.). Anhydrous potassium carbonate was purchased from J.T. Baker (Phillipsburg, NJ, U.S.A.). 1-Chlorobutane (Aldrich), acetonitrile (J.T.Baker), and triethylamine (J.T.Baker) were all HPLC grade. Acetonitrile used for derivatization was dried over mo-

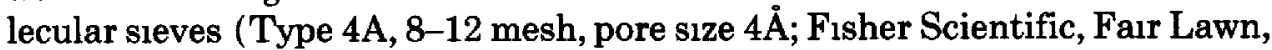
NJ, U.S.A.).

A polyurethane two-component system (Tecoflex 2-80A, Thermedics, Woburn, MA, U.S.A.) was used for preparing the controlled-release matrices, and ferric chloride (Fisher) was used as a catalyst in the polymerization [11].

Canıne plasma was obtained during the course of dog experiments concerned with controlled-release lidocaine administration [12]. Freshly obtained dog plasma obtained both prior to and after lidocaine administration was stored at $-20^{\circ} \mathrm{C}$ Fresh frozen human plasma obtaned from subjects who were not receiving lidocaine was provided by the University of Michigan Blood Bank.

\section{Apparatus}

Liquid chromatographic analyses were performed on a Waters Model 501 (Waters, Milford, MA, U.S.A.) hıgh-performance liquid chromatograph, which was equipped with a prepared $\mathrm{C}_{18}$ column (Waters $\mu$ Bondapak ${ }^{\mathrm{TM}} \mathrm{C}_{18}, 15 \mathrm{~cm}$ $\times 3.9 \mathrm{~mm}$ I.D., particle size $10 \mu \mathrm{m}$ ). The column temperature was maintained at $30^{\circ} \mathrm{C}$ with a column heater and temperature control modules (Waters) The detection of the lidocaine derivative was carried out with a Waters 420 fluorescence detector. A combination of a 254-nm-bandpass excitation filter, a 313nm-bandpass emission filter, and a mercury source lamp G4T5 (Waters filters kit) was used. Data was recorded on a Waters 740 Data Module single-channel integrator.

\section{Sample preparation}

Extraction Aliquots $(0.5-1.0 \mathrm{ml})$ of dog or human plasma (non-lidocainecontaining) were spiked with appropriate amounts of lidocaine aqueous solution $(1 \mu \mathrm{m} / \mathrm{ml})$, followed by the addition of $50 \mu \mathrm{l}$ of internal standard solution (10 $\mu \mathrm{g} / \mathrm{ml}$ ), $0.2 \mathrm{ml}$ of $1 M$ sodium hydroxide, and $3 \mathrm{ml}$ of 1 -chlorobutane. Soduum hydroxide was used in order to convert lidocaine hydrochloride to its free base, which can be extracted into the organic phase and reacted with 9-FMClF. After vortexing, the organic layer was separated The organic layer was next evaporated to dryness under vacuum and the residue derivatized.

Derivatızatıon The dried residues in 5-ml tubes were redissolved in $0.4 \mathrm{ml}$ of anhydrous acetonitrile followed by an addition of $50 \mu \mathrm{l}$ saturated solution of potassium carbonate in acetonitrile. A $50-\mu \mathrm{l}$ volume of a freshly prepared so- 
lution of $9-\mathrm{FMClF}$ reagent in acetonitrile $(1 \mathrm{mg} / \mathrm{ml})$ was then added The mixtures were vortexed and incubated in open tubes at $110^{\circ} \mathrm{C}$ for $60 \mathrm{~min}$. The tubes were allowed to cool and the residues were redissolved in $0.1 \mathrm{ml}$ of acetonitrile. Samples of $20 \mu \mathrm{l}$ were injected into the HPLC system.

\section{High-performance liquld chromatography}

Plasma samples were analyzed usıng an 1socratic mobile phase consisting of an aqueous $0.02 \%$ acetic acid solution adjusted to $\mathrm{pH} 6.8$ with triethylamine and combined in a 4060 ratio with acetonitrile. A flow-rate of $2 \mathrm{ml} / \mathrm{min}$ was used. Fluorescence detection was carried out with excitation and emission filters of 254 and $313 \mathrm{~nm}$, respectively. The data were analyzed using a sevenpoint calibration curve which was run for every series of chromatographed samples

\section{Recovery}

Varıous aliquots of lidocaine hydrochloride solution $(1 \mu \mathrm{g} / \mathrm{ml})$ were mixed with $1 \mathrm{ml}$ of drug-free plasma and the samples were analyzed according to the extraction procedure described above. For these analyses, the internal standard solution in anhydrous acetonitrile was added after the extraction was terminated. A series of external standards was prepared by adding the same amounts of internal standard solution to a set of various alıquots of lidocaine free base solution $(1 \mu \mathrm{g} / \mathrm{ml})$ (see Chemicals). Prior to the determination of lidocaine by HPLC, the solutions were concentrated to dryness under vacuum $\left(\right.$ at $55^{\circ} \mathrm{C}$ ) and derivatized as described above. Analytical recoveries were calculated by comparing peak-area ratios of the extracted standards to a calibration graph constructed for lidocaine base from the external standards' set.

\section{Precision}

Four aliquots $(10 \mathrm{ml})$ of canıne and human plasma were spiked with the appropriate amounts of lidocaine hydrochloride to achieve concentrations of $50,100,150$, and $200 \mathrm{ng} / \mathrm{ml}$ and were then stored at $-20^{\circ} \mathrm{C}$ for two weeks $\mathrm{On}$ different days, 1-ml samples were taken from the various stored alıquots and analyzed. The data were compared with a fresh calibration curve which was constructed from standard samples extracted on the same day.

\section{Synthesus of the 9-fluorenylmethyloxycarbonyl derivatue of lidocaine}

Lidocaine base or EMGX, which differs from lidocaine by the substitution of one ethyl by a methyl group $(0.002 \mathrm{~mol})$ was dissolved in $5 \mathrm{ml}$ of a saturated solution of potassium carbonate in anhydrous acetonitrile. 9-FMClF $(0.006$ mol) was added, and the solution was mixed and placed in an oven at $110^{\circ} \mathrm{C}$. Samples of $1 \mu \mathrm{l}$ were taken periodically and spotted on a thin-layer chromatography (TLC) plate (precoated silica gel 60, layer thickness $02 \mathrm{~mm}, \mathrm{E}$. Merck, Darmstadt, F.R.G.) and were subsequently developed with hexane- 
ethyl acetate-methylene chloride ( $\left.\begin{array}{lll}60 & 20 & 20\end{array}\right)$. Using short-wavelength UV detection, the reaction progress was traced until completion after $6 \mathrm{~h}$. Portions of the solution were then taken on preparative TLC plates (precoated silica gel 60 , layer thickness $2 \mathrm{~mm}$ ) and chromatographed using the same development described above. After separation, silica bands were scraped from the plate, extracted with acetonitrile, and filtered. The acetonitrile was evaporated and the residual oll was identified by mass spectral analysis, using a fast atom bombardment instrument (VG Analytical 70-250S, Manchester, U.K.).

\section{Controlled-release matrix and experimental ventricular tachycardıa}

Lidocaine hydrochloride matrices were formulated as $28 \%$ dispersions in a reactive mixture of Tecoflex $80 \mathrm{~A}$ polyurethane according to a previously related technique [11]. In an open-chest dog (male mongrel, $20 \mathrm{~kg}$ ) preparation, VT was induced by rapid ventricular pacing [12] at a cycle length of $50 \mathrm{~ms}$ using the methodology of Toda et al. [16]. After the induction of VT, a lidocaine hydrochloride-polyurethane matrix $(5 \mathrm{~mm} \times 5 \mathrm{~mm}, 44 \mathrm{mg})$ was placed adjacent to the stimulating electrode. During in vivo controlled release and eventual conversion of the VT to sinus rhythm, blood samples were taken s1multaneously from the coronary vein $(0.3-0.5 \mathrm{ml}$ per sample) and from the femoral artery $(5 \mathrm{ml})$ through indwelling catheters

\section{RESULTS AND DISCUSSION}

\section{Characterization of chloroformate reaction and lidocaine derivatives}

Carbamates derived from tertiary amines have been already used in gas chromatography [17-22] and in HPLC [15-23]. In their publications concerned with reactions of various chloroformates with tertiary amines, Karlsson and Hartvig [24-26], Gubitz et al. [23], and Kometani et al [27] suggest that a reactive intermediate compound is formed in the reaction, e.g. quaternary ammonium ion. This intermediate compound was found to be unstable and susceptible to (a) hydrolysis (in a polar solvent such as water) and (b) nucleophilic attack of chlorine ions (in a less polar solvent such as methylene chloride), resulting to the formation of the original amine (a) and a stable carbamate and alkylhalide (b).

In contrast to the above publications we found that, under the conditions described in this report, the tertiary amine molety of lidocaine reacts with two equivalents of the chloroformate (9-FMClF), resulting in a stable ionic form of dicarbamate (Fig. 1). This compound was stable at room temperature for at least three days, based on repeating HPLC analyses. Only one ethyl group in both, lidocaine and EMGX, was degraded (F1g. 1), suggestıng two important findings: (a) the tendency to cause nitrogen-alkyl (N-R) cleavage favoured the ethyl group over the methyl group, and this is in contrast to the finding of Kometani et al. [27], (b) the elimination of the other alkyl group, due to the 
1

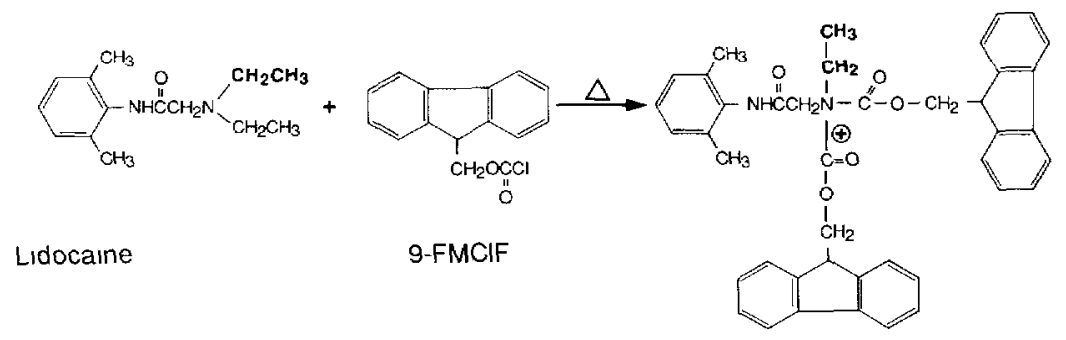

bis( 9-Fluorenylmethyloxycarbonyl-judocane

2

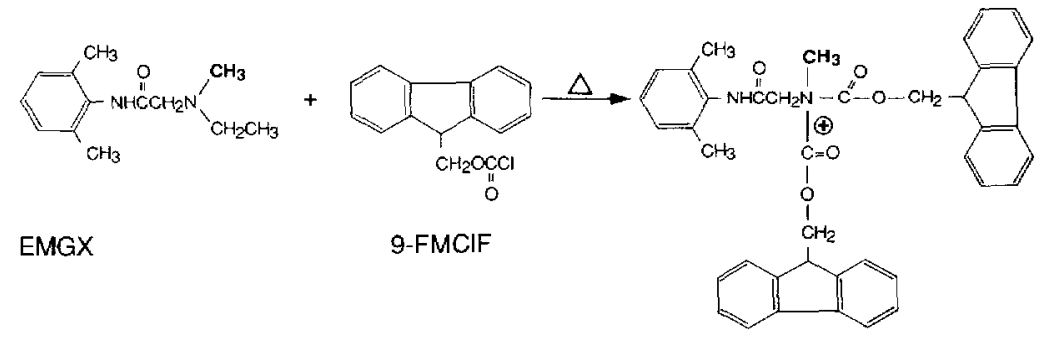

bıs(-9-Fluorenylmethyloxycarbonyl-)EMGX

Fig 1 Reaction of lidocaine (as the free base) or EMGX with 9-fluorenylmethylchloroformate (9-FMClF)

reaction of the second chloroformate molecule, is suppressed, probably because of a steric hindrance in the resultant compound.

Evaluation of the analytical procedure

Typical chromatograms of the derivatives of lidocaine and NME from plasma extracts are presented in Fig. 2. Under the assay conditions used, reproducible retention times of 148 and $11.5 \mathrm{~min}$ were obtained for lidocaine and $\mathrm{N}$-methylephedrine, respectively. There was no interference from endogenous plasma compounds. Plots of the calibration curves of plasma lidocaine [peak-area ratio of drug to its respective internal standard $(y)$ versus drug concentration $(x)$ ] over the range $25-500 \mathrm{ng} / \mathrm{ml}$ were linear The linear regression equation was $y=0.012 x(r=0999)$ for dog plasma and $y=0.011 x(r=0.981)$ for human plasma The lower limit of detection was $1 \mathrm{ng}$ per injection.

1-Chlorobutane was used in this assay as the extraction solvent and was shown to be very efficient (about $80 \%$ lidocaine recovery from dog and human plasma and virtually no interferıng compounds detected on HPLC) Chromatographic experiments were performed using both $\mathrm{C}_{18}$ ( 5 and $10 \mu \mathrm{m}$ particle size) reversed-phase columns and cyano-bonded phase columns with various mobile phase compositions. The optimum resolution for the plasma extracts was achieved by using a $\mathrm{C}_{18}$ reversed-phase column ( $10 \mu \mathrm{m}$ partıcle size $)$. Trıethylamine was found to be an essential component in the mobile phase in 
A

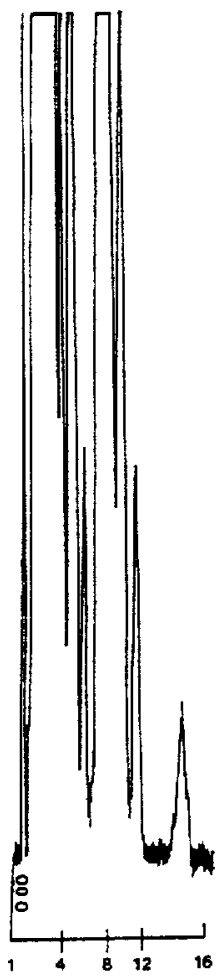

B

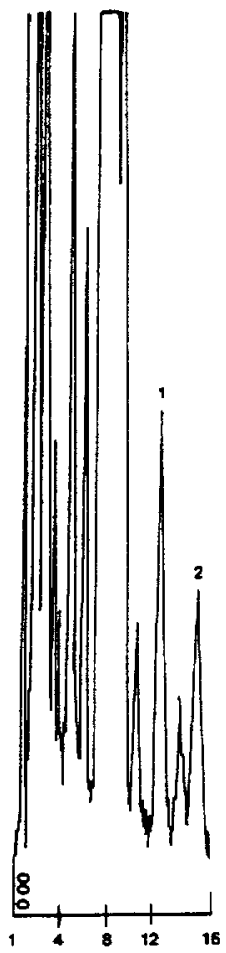

C

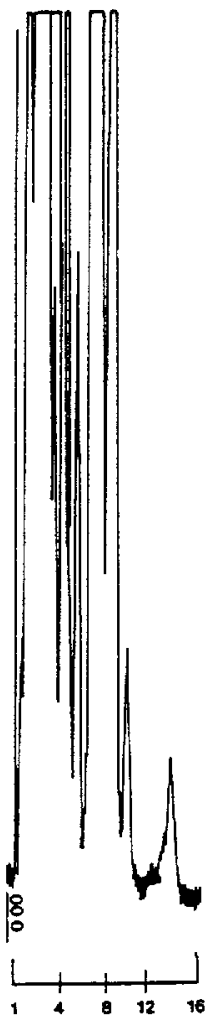

D

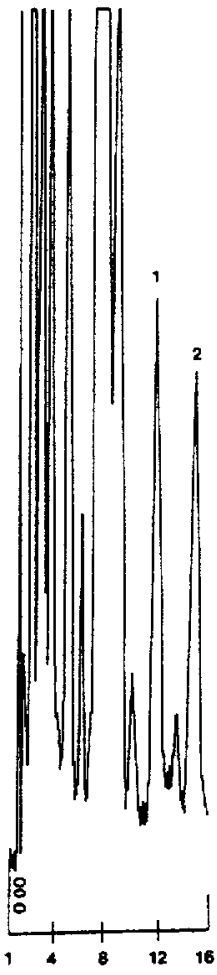

Fig 2 HPLC profiles of the 9-fluoromethyloxycarbonyl derivatives of lidocaine (A) Extract of non-lidocaine-containıng (blank) dog plasma, (B) dog plasma containing internal standard (1) and lidocaine (2), $150 \mathrm{ng} / \mathrm{ml}$, (C) extract of non-lidocaine-containing (blank) human plasma, (D) human plasma containıng internal standard (1) and hdocaine (2), $150 \mathrm{ng} / \mathrm{ml}$

achieving narrow peaks and in elıminating interferıng tailing peaks, whıch appeared sometimes in plasma extracts.

\section{Assay valudation}

The extraction efficiency or the recovery of lidocaine hydrochloride was determined as described in the Experimental section. Table I shows the recoveries in various lidocaine plasma levels; the average extractıon efficiencies were $77.4 \pm 3.0$ and $88.6 \pm 3.6 \%$ from dog and human plasma, respectively

Assay precision was established by performing seven replicate analyses of four control samples containıng $50,100,150$, and $200 \mathrm{ng} / \mathrm{ml}$ lidocaine on different days during a two-week period. The replicate samples were extracted, derivatized, and chromatographed as described in the Experımental section. 


\section{TABLE I}

EXTRACTION EFFICIENCY OF VARIOUS CONCENTRATIONS OF LIDOCAINE FROM 1-ml ALIQUOTS OF CANINE AND HUMAN PLASMA

\begin{tabular}{|c|c|c|c|c|}
\hline \multirow{2}{*}{$\begin{array}{l}\text { Actual } \\
\text { concentration } \\
(\mathrm{ng} / \mathrm{ml})\end{array}$} & \multicolumn{2}{|c|}{ Recovered concentration ( $\mathrm{ng} / \mathrm{ml})$} & \multicolumn{2}{|c|}{ Recovery (\%) } \\
\hline & Canıne & Human & Canıne & Human \\
\hline 25 & 194 & 208 & 776 & 832 \\
\hline 50 & 420 & 381 & 840 & 762 \\
\hline 75 & 632 & 650 & 843 & 867 \\
\hline 100 & 614 & 994 & 614 & 994 \\
\hline 125 & 934 & 1059 & 747 & 847 \\
\hline 150 & 1186 & 1296 & 791 & 864 \\
\hline 200 & 1616 & 2065 & 808 & 1033 \\
\hline Mean & & & 774 & 886 \\
\hline$S \mathrm{E}$ & & & 296 & 358 \\
\hline SD & & & 784 & 946 \\
\hline
\end{tabular}

\section{TABLE II}

ASSAY PRECISION DATA FOR LIDOCAINE DETERMINATION IN CANINE AND HUMAN PLASMA

\begin{tabular}{|c|c|c|c|c|}
\hline \multirow{2}{*}{$\begin{array}{l}\text { Actual } \\
\text { concentration } \\
(\mathrm{ng} / \mathrm{ml})\end{array}$} & \multicolumn{2}{|c|}{ Assayed concentration ${ }^{a}(\mathrm{ng} / \mathrm{ml})$} & \multicolumn{2}{|c|}{ Standard error of the mean $(\mathrm{ng} / \mathrm{ml})$} \\
\hline & Canine & Human & Canıne & Human \\
\hline 50 & 443 & 555 & 42 & 40 \\
\hline 100 & 882 & 1139 & 101 & 135 \\
\hline 150 & 1598 & 1557 & 231 & 173 \\
\hline 200 & 1905 & 2002 & 164 & 205 \\
\hline
\end{tabular}

${ }^{a}$ Mean of seven determinations

The results are shown in Table II The observed values of the various levels of lidocaine as measured chromatographically were not significantly different from the actual concentrations (Table II)

\section{Applicablltty of the assay to biological studies}

The biomedical application and the utility of the HPI.C method was demonstrated by a pharmacokınetic study performed with controlled-release $\mathrm{l}_{1}$ docaine matrices In this study a lidocaine-polyurethane matrix [ $28 \%(\mathrm{w} / \mathrm{w})$, $44 \mathrm{mg}, 5 \mathrm{~mm} \times 5 \mathrm{~mm}$ ] was placed on the left ventricular epicardium adjacent to a pacing electrode in order to convert experimental VT in a dog model to sinus rhythm as previously described [12]. As shown in Fig 3, the regional coronary venous plasma levels of lidocaine were in the range $08-2.3 \mu \mathrm{g} / \mathrm{ml}$ 


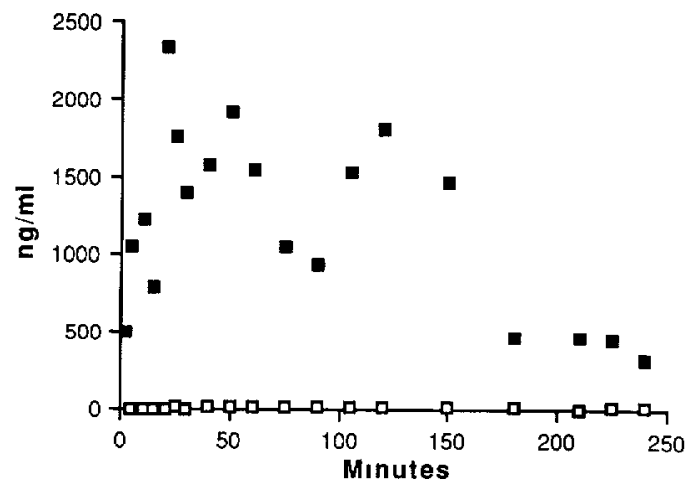

Fig 3 Lidocaine plasma levels obtained during a 4-h epicardial matrix application [1idocainepolyurethane, $28 \%$ (w/w) $, 44 \mathrm{mg}, 5 \mathrm{~mm} \times 5 \mathrm{~mm}$, delivering total dose of $920 \mu \mathrm{g} / \mathrm{kg}$ ] in an openchest dog preparation Lidocaine was measured in coronary plasma ( $\square$ ) and in peripheral plasma ( $\square)$

while simultaneous peripheral blood levels were about 100 -fold lower (5.4-20.3 $\mathrm{ng} / \mathrm{ml}$ ). These findings emphasize the site-specificity of this administration, the prolonged action of the device, and suggest that the controlled-release lidocaine may be an alternative to high systemic drug exposure which may be associated with adverse effects.

An additional series of experiments were carried out in an attempt to derivatize the principal metabolite of lidocaine, monoethylglycylxylidide (MEGX) with 9-FMCIF, and achieve an HPLC separation using the conditions described above. However, an inadequate yıeld of the product was obtained and plasma concentrations of MEGX less than $200 \mathrm{ng} / \mathrm{ml}$ could not be detected.

In conclusion the HPLC method described is relatively simple and has an adequate sensitivity and precision to be used for pharmacokinetic studies following a low dose of controlled-release lidocaine. This rapid fluorometric method for assaying $\mathrm{ng} / \mathrm{ml}$ levels of lidocaine should prove to be especially useful for studies of controlled-release lidocaine administered directly to the heart

\section{REFERENCES}

1 M Malach, J B Kostıs and J L Fischett1, Am J Med Sc1, 257 (1969) 52

2 R Gianelli, J O Van der Groeben, A P Spivack and D C Harrison, N Engl J Med, 277 (1967) 1215

3 P K Narang, W G Crouthamel, N H Carlıner and M L Fisher, Clin Pharmacol Ther, 24 (1978) 654

4 K Kushıda, K Oda, T Suganuma and T Ishızakı, Clın Chem, 30 (1984) 637

5 F A Luzzı, T L Wenger, J K Klinger, A Barchowsky and H C Strauss, J Chromatogr, 311 (1984) 291

6 R Kawaı, S Fujıta and T Suzukı, J Pharm Scı, 74 (1985) 1219

7 N Daoud, T Arvidsson and K G Wahlund, J Pharm Biomed Anal, 5 (1987) 533 
8 H R Angelo, J Bonde, J P Kampmann and J Kastrup, Scand J Clin Lab Invest, 46 (1986) 623

9 K A Collınsworth, S M Kalman and D C Harrıson, Circulation, 50 (1974) 1217

10 O B Garfein, Ther Drug Mont , 4 (1982) 1

11 A Sintov, W Scott, M Dick and R J Levy, J Controlled Rel , 8 (1988) 151

12 A Sintov, W Scott, R Siden and R J Levy, in W Ensminger (Editor), Infusion Systems in Medicine, Futura Publishing, Mount Kisco, NY, 1988, in press

13 J Meienhofer, M Wakı, E P Heimer, T J Lambros, R C Makofske and C D Chang, Int J Pepl Prulein Res, 13 (1979) 35

14 C D Chang, M Wakı, M Ahmad, J Meienhofer, E O Lundell and J D Haug, Int J Pept Protein Res , 15 (1980) 59

15 J A Shah and D J Weber, J Chromatogr, 309 (1984) 95

16 I Toda, Y Murakamı, A Nozak1, K Kawakubo and T Sugımoto, Jpn Circ J , 52 (1988) 249

17 P Hartvig and J Vessman, Acta Pharm Suec, 11 (1974) 115

18 P Hartvig, N O Ahnfelt and K E Karlsson, Acta Pharm Suec, 13 (1976) 181

19 P Hartvig, K E Karlsson, L Johansson and C Lindberg, J Chromatogr, 121 (1976) 235

20 P Hartvig, K E Karlsson, C Lındberg and L O Boreus, Eur J Clın Pharmacol , 11 (1977) 65

21 T Yamaguchı, S Yoshıkawa, Y Sekıne and M Hashımoto, J Chromatogr , 173 (1979) 147

22 K E Karlsson, J Chromatogr , 219 (1981) 373

23 G Gubitz, R Wintersteiger and A Hartinger, J Chromatogr , 218 (1981) 51

24 K E Karlsson and P Hartvig, Acta Pharm Suec, 17 (1980) 249

25 K E Karlsson and P Hartvig, Acta Pharm Suec, 18 (1981) 193

26 K E Karlsson and P Hartvig, Acta Pharm Suec, 18 (1981) 337

27 T Kometanı, S Shıtanı and K Mitsuhash,, Chem Pharm Bull , 24 (1976) 342 